\title{
Porto, praça e palco: as ruas da cidade como espaços de educação
}

DOI: https://doi.org/10.22409/pragmatizes.v11i20.45784

\section{João Guerreiro ${ }^{1}$}

Luísa Reis ${ }^{2}$

\begin{abstract}
Resumo: A partir das narrativas de encontros que se dão nas ruas, em aulas de teatro feitas em uma praça da zona portuária do Rio de Janeiro, esse artigo busca discutir as potencialidades do fazer teatral com crianças em espaços públicos. O texto contextualiza e examina as constantes modificações urbanas na zona portuária, área central do Rio de Janeiro, desde a constituição do Morro da Favela, hoje Morro da Providência, até a atualidade. Nesse processo de transformações impostas pelo poder público, a articulação dos projetos culturais e sociais do e no território atuam no sentido de articular com os moradores e habitantes da zona portuária outros usos para o espaço. $\mathrm{O}$ encontro de dois projetos educativos, o Viaduto Literário e o Projeto Teatro Nômade, que trabalham desde 2018 na fronteira entre os morros do Pinto e da Providência, coloca novas questões sobre a ocupação desse espaço urbano, que se apresenta então como palco e sala de aula, como um espaço de ensino-aprendizagem.
\end{abstract}

Palavras-chave: Morro da Providência; Porto Maravilha; pedagogia do teatro; rua.

Puerto, plaza, escenario: las calles de la ciudad como espacios de educación

Resumen: Con base en las narrativas de los encuentros en la calle y en las clases de teatro en una plaza de la zona portuaria de la ciudad de Río de Janeiro, el artículo propone abrir un debate sobre el potencial del ejercicio del arte teatral con niños en espacios públicos. El texto contextualiza y examina el proceso de transformaciones urbanas en esta región central de la ciudad llevada a cabo por las autoridades públicas en diferentes momentos, desde la constitución del Morro da Favela, hoy Morro da Providência, hasta la actualidad. En este proceso de transformaciones impuestas por el poder público, la articulación de los proyectos culturales y sociales de y en el territorio actúan para articular con los residentes y habitantes del área portuaria otros usos del espacio. El encuentro de dos proyectos educativos, el Viaduto Literário (Viaducto Literario) y el Projeto Teatro Nômade (Proyecto Teatro Nómada), que funcionan desde 2018 en la frontera entre el Morro da Providência y el Morro do Pinto, plantea nuevos interrogantes sobre la ocupación de este espacio urbano, que se presenta entonces como escenario y aula, como espacio de enseñanza y aprendizaje.

Palabras clave: Morro da Providência; Porto Maravilha; pedagogía teatral; calle.

\footnotetext{
${ }^{1}$ João Luiz Guerreiro Mendes. Doutor em Políticas Públicas de Cultura pela Universidade Federal do Rio de Janeiro (UFRJ). Professor do Bacharelado em Produção Cultural do Instituto Federal do Rio de Janeiro (IFRJ), Brasil.E-mail:joao.mendes@ifrj.edu.br - https://orcid.org/0000-0003-1788-4132

${ }^{2}$ Luísa Valença Reis. Mestranda em Educação pela Universidade Federal Fluminense (UFF), Brasil. E-mail:Iuisavreis@gmail.com - https://orcid.org/0000-0001-6085-8218
} 
Port, square, stage: city streets as educations places

\begin{abstract}
Based on the narratives of encounters that take place on the streets, in drama classes in a square in the port area of Rio de Janeiro, this article seeks to discuss the potential of making theatre with children in public spaces. The text contextualizes the constant urban changes in the port area, central area of Rio de Janeiro, from the constitution of Morro da Favela, today called Morro da Providência, to the present day. In this process of transformations imposed by the public authorities, the articulation of cultural and social projects in the territory act to articulate other uses for space with residents and inhabitants of the port area. The meeting between two educational projects, the Viaduto Literário (Literary Viaduct) and the Projeto Teatro Nômade (Nomadic Theater Project), which have been working since 2018 on the border between Morro do Pinto and Morro da Providência, raises new questions about the occupation of this urban space, which then presents itself as a stage and classroom, as a teaching-learning space.
\end{abstract}

Keywords: Morro da Providência; Porto Maravilha; theater pedagogy; street.

\title{
Porto, praça e palco: as ruas da cidade como espaços de educação
}

\section{Apresentação}

Esse é um texto sobre fronteiras, encontros e potências. Iremos narrar o encontro entre dois projetos realizados na fronteira entre o Morro da Providência e o Morro do Pinto, na zona portuária do Rio de Janeiro. Apresentaremos como o "Projeto Teatro Nômade", que ocupa cenicamente espaços públicos da cidade, começou sua caminhada sob o Viaduto São Pedro/São Paulo ao se encontrar com o projeto "Viaduto Literário".

Inicialmente apresentaremos a constituição da região portuária do Rio de Janeiro, a sua ocupação e suas transformações no decorrer dos séculos até chegarmos aos projetos culturais que hoje marcam o território. A seguir, narraremos a chegada do "Nômade" e discutiremos as construções, potencialidades, as aprendizagens em fazer teatro junto com crianças e adolescentes de uma região periférica, mesmo que inserida em uma das áreas com maior quantidade e qualidade de infraestrutura da cidade do Rio de Janeiro.

\section{E a nau retorna ao porto}

A Praça da Marquês, situada embaixo do Viaduto São Pedro/São Paulo, divisão de concreto que delimita os espaços dos morros do Pinto e da Providência, é um ponto de encontro para os moradores do seu entorno. A 
praça, ou o Viaduto, como chamamos, tem sido um espaço de convivência, festa, troca, criação e educação.

Desde 2018, o Projeto Teatro Nômade também ocupa a Praça da Marquês. O Nômade é um projeto artístico-educativo que entende que o teatro é uma prática de todos e em todos os espaços. Não há lugar, corpo ou pessoa ideal para "fazer teatro". Ele oferece aulas e apresentações teatrais em condições possíveis: nas ruas, bibliotecas, pátios de escolas, salas de casas, plays de condomínios.É Nômade, pois onde houver alguém disposto a produzir conhecimentossignificações ${ }^{3}$ com 0 teatro, estará lá, e assim poderá criar redes artístico-educativas para além do momento presente de uma aula ou de uma apresentação. Esse entendimento dialoga com Augusto Boal, diretor, pesquisador e sistematizador do Teatro do Oprimido, que pode ser considerado um conjunto de jogos e exercícios que visam a

\footnotetext{
${ }^{3}$ Neste texto, usamos as expressões conhecimentossignificações e aprenderensinar de forma aglutinada para enfatizar o quanto compõem a mesma ação, buscando romper com a dicotomia que separa os processos de produção do conhecimento em dimensões internas e externas da escola e os processos de aprender e ensinar.
}

transformação social por meio do teatro.

Todos os seres humanos são atores, porque agem, e espectadores, porque observam. Somos todos espect-atores. (...) A palavra teatro é tão rica em significados diferentes (...) que nunca sabemos ao certo sobre o que estamos falando quando falamos de teatro. (...) No sentido mais arcaico do termo, porém, teatro é a capacidade dos seres humanos (ausente nos animais) de se observarem a si mesmos em ação. Os humanos são capazes de se ver no ato de ver, capazes de pensar suas emoções e de se emocionar com seus pensamentos. Podem se ver aqui e se imaginar adiante, podem se ver como são agora e se imaginar como serão amanhã. (BOAL, 2011, p. ix, xiii, xiv)

Mas antes de chegarmos sob o viaduto que separa o Morro da Providência do Morro do Pinto, e que faz a ligação entre a zona sul e a zona portuária do Rio de Janeiro, achamos importante mostrar a constituição deste espaço periférico que ladeia a área de negócios central da cidade do Rio de Janeiro, e como essa formação histórica perpassa até hoje os encontros que se dão nesse território.

No decorrer de séculos a região portuária da cidade do Rio de Janeiro passou por diversas mudanças. Considerada por muitos pesquisadores como o primeiro grande marco na ocupação dessa área, em meados da década de 1770, ocorreu a 
transferência do mercado de pessoas escravizadas da atual Praça Quinze e arredores para a região do Valongo (hoje bairros da Saúde, Gamboa e Santo Cristo). Nas palavras do então Vice-Rei, Marquês do Lavradio, responsável pela transferência, e que hoje é homenageado em uma rua que reúne ironicamente uma famosa feira na cidade no primeiro sábado de cada mês,

as pessoas honestas não se atreviam a chegar às janelas; as que eram inocentes ali aprendiam o que ignoravam e não deviam saber. Logo que desembarcavam, vinham para as ruas, cheios de infinitas moléstias... e ali mesmos faziam todo que a natureza lhes lembrava, não só causando o maior fétido... mas até sendo o espetáculo mais horroroso que se podia apresentar aos olhos. (ATHAYDE, 2001, p. 8)

A capital tinha sido transferida de Salvador para o Rio de Janeiro uma década antes e, assim, aos olhos do governante geral da colônia, o centro da sua nova capital precisava se modernizar e tornar-se mais embelezada para as elites.

A mudança do local de recebimento dos negros escravizados provocou o surgimento de novas atividades econômicas na região. As antigas chácaras foram loteadas e as hortas que abasteciam o núcleo urbano da cidade foram paulatinamente dando lugar aos armazéns, trapiches e pequenas manufaturas. Os pântanos foram aterrados e começaram a dar lugares às ruas e pequenos ancoradouros. Surgiria, inclusive, o cemitério dos Pretos Novos.

O cemitério recebeu esse nome por ser um local onde foram depositados os restos mortais de milhares de africanos que foram escravizados e foram trazidos para o Brasil. Muitos que lá estão chegaram ao país já mortos. Outros morriam assim que chegavam e outros, também enterrados nesse cemitério, teriam morrido já no processo de trabalho. Em comum, está o anonimato desses africanos. Segundo pesquisas realizadas pelo Instituto Pretos Novos ${ }^{4}$, o cemitério foi construído no mesmo ano da transferência do mercado dos escravizados, em 1770, e desativado em 1831.

Se o Oceano Atlântico, chamado por Paul Gilroy como o Atlântico Negro, é para muitos, o lugar

\footnotetext{
${ }^{4}$ Entrevista concedida pela coordenadora do IPN a um dos autores desse artigo em 2013.
} 
das trocas culturais exercidas durante a diáspora africana no auge da escravidão negra, o cemitério acompanha esta trajetória pelo Atlântico. Sempre próximo aos mercados de escravos nas praias, os cemitérios tornaram-se o fim da diáspora para muitos.

No decorrer do século XIX, principalmente a partir da vinda da família real portuguesa em 1808 para - Brasil até a proibição do tráfico de negros escravizados, em 1850, as chácaras nas áreas de planície da região portuária continuaram sofrendo um processo de loteamento. Segundo Mello (2003), esse processo vai gerar as bases para o surgimento de três bairros: Saúde, Gamboa e Santo Cristo. E, mais, pelo tipo de atividade econômica surgida desde o século XVIII, a região vai se articular com o núcleo da cidade através das atividades portuárias e atividades relacionadas ao mercado de pessoas negras escravizadas. Começava a ser estabelecida uma hierarquia secundarizada da região, apesar de ser importante para o desenvolvimento da cidade (MELLO, 2003). Em outras palavras, a região portuária passava a se configurar como uma periferia do núcleo da região central da cidade.

Para alguns autores, como Lamarão (1984) e Benchimol (1982), o processo de loteamento e fracionamento das chácaras e quintais na região portuária levou seus antigos moradores a se transferirem para as novas áreas de expansão urbana com nível de renda mais elevado, como os bairros do Flamengo e Botafogo ambos localizados no que se convencionou chamar de zona sul da cidade do Rio de Janeiro. Lamarão chega a afirmar que a região sofreu um processo de homogeneização dos estratos sociais "de baixo" e, com isso,

chega ao século $X X$ carregada de adjetivos que a desqualificam, que a estigmatizam frente à cidade. Identificada como a parte do centro urbano que concentrava o grosso das atividades portuárias, onde os navios mercantes ancoravam e as mercadorias ficavam depositadas, reduzida a um labirinto de becos e vielas, a uma infinidade de trapiches e oficinas, ela é uma nódoa, algo que incomoda concretamente uma elite que incorpora com rapidez os valores burgueses, substrato ideológico do processo de transição para o capitalismo.

Ela incomoda porque sua numerosa e concentrada população composta de brancos e negros, brasileiros e estrangeiros, operários, trabalhadores da estiva, biscateiros, ambulantes desempregados, - é pobre, amontoa-se em precários 
cortiços, e morre aos montes, vitimada pelas epidemias. Área densa, populosa, pobre, insalubre... e perigosa. Os quarteirões marítimos, o bairro "rubro" da cidade e, o "homizio predileto dos valentões" servem de cenário a crimes que levam a Saúde, a Gamboa e o saco de Alferes às primeiras páginas dos jornais. (LAMARÃO, 1984, p. 115)

$E$ é no final do século XIX que

há a consolidação desse processo com o surgimento da primeira favela do país: o Morro da Favella. Localizada entre o Morro da Conceição e o Morro do Pinto, o Morro da Favella, atual Morro da Providência, tem o início de sua ocupação nesse período. Mesmo não sendo possível designar eventos que expliquem a sua ocupação, temos um somatório de acontecimentos que ajudaram a gerar hipóteses sobre o surgimento da habitação no local.

De Paula (2004) sustenta que a destruição do maior cortiço da então capital nacional, o Cabeça de Porco, iria iniciar uma prática de ocupação dos morros da capital do país, iniciando pelo Morro da Providência. Segundo o autor,

Num ato de magnânima bondade, o prefeito [Barata Ribeiro] permitiu aos moradores recolherem madeiras que sobraram sob os escombros, onde, sem demora, os moradores que não conseguiram outros locais de moradia construíram barracos na encosta que ficava no fundo do terreno, que ainda pertencia aos antigos proprietários do cortiço. Dessa forma, plantou-se um núcleo de habitação no morro que pouco mais tarde, em 1897, seria ocupado pelos soldados que retornaram de Canudos. Com a queda do célebre cortiço, o Rio de Janeiro presenciou o início da transição de uma era, 'a semente de favela' saiu do cortiço, deixou a cidade e subiu o morro (DE PAULA, 2004, p. 53)

Conforme apresentado pelo autor, outro grupo que iria ocupar o Morro da Favella, é o formado por soldados que retornaram da Guerra de Canudos (BA), em 1897. Ao não receberem o que lhes havia sido prometido pelo governo, subiram o morro atrás do então Ministério da Guerra, e ficaram aguardando a recompensa. Abreu e Vaz (1991) sustentam a tese que a falta de moradias suficientes para atender a população que, por motivos diversos, chegava à capital do país demonstra a contradição das transformações que vão ocorrer na região central do Rio de Janeiro. E é essa separação entre os usos e as classes na cidade que a ocupação do Morro da Favella evidencia (ABREU, 1988).

Cabe-nos fazer um parêntese para ressaltar que ao se dar o nome de Morro da Favella para essa primeira ocupação por moradores de 
baixa renda, que originariamente seria o de uma planta existente em Canudos ou de um morro existente no então Arraiá de Canudos, o morro acaba assumindo uma nova classificação. A ocupação dos morros por população de baixa renda, com pouca ou nenhuma infraestrutura sanitária ou serviços públicos, sem arruamento e com habitações provisórias, acaba sendo sinônimo de um reduto de pobreza. Assim, o Morro da Favella acaba representando o que Lamarão chamou de reduto dos estratos sociais "de baixo".

Porém, Zylberberg (1992) vai salientar que a região onde está localizado o Morro da Providência teve outras denominações antes de ser "rebatizada" de Morro da Favella: "Paulo Caieiro", "Formiga", "Livramento", "Valongo", "Santana", "São Lourenço". Segundo a autora, "Morro da Providência" já aparecia, em 1850, para denominar a parte da região que fica próxima ao Morro do Pinto. Já a parte que faz fronteira com o Morro da Conceição era conhecida como Morro do Livramento. Mas a denominação "Morro da Providência" voltará a designar toda a região. E o termo "favela" passará a designar as habitações provisórias que irão constituir as moradias da população de baixa renda, inicialmente, nos diversos morros da cidade e, posteriormente, atravessarão as fronteiras da cidade, estado e até do país.

E é em uma das fronteiras da cidade - entre o Morro do Pinto e o atual Morro da Providência - que o Projeto Teatro Nômade atua. Uma das autoras desse artigo é professora do Nômade, dando aulas de teatro nas ruas para adolescentes desde 2017, em praças variadas da zona sul da cidade. Em 2019, o projeto iniciou a turma infantil de teatro de rua na Praça da Marquês, que fica sob o viaduto que hoje marca, para os moradores, a fronteira entre as duas favelas. Essa turma conta também com a professora Lorrana Mousinho, e as duas educadoras, logo nos primeiros dias de encontros com as crianças, puderam perceber que ali as dificuldades pareciam as mesmas de ocupar as ruas da zona sul com adolescentes,mas carregavam muitas diferenças.

Quando começamos a dar aula de teatro na rua, nos habituamos a perder a atenção da turma para os cachorros que passavam querendo 
carinho dos alunos. Na Praça da Marquês, embora também tivéssemos uma grande circulação de animais durante a aula, era na passagem da patrulhinha da PM que as crianças se alvoroçavam, com reações que iam do medo ao enfrentamento.A ocupação histórica desse território, narrada até aqui, se inicia com violência e abandono do poder instituído e aponta para uma profunda discriminação dos moradores que passaram a habitar os morros da região. A reação das crianças, com idades de quatro a dez anos, ao verem a polícia chegar, pode significar que a relação com o Estado parece não ter se alterado ao longo dos séculos, apesar das tentativas de novas modificações urbanas na área, como veremos a seguir.

\section{O porto, os projetos urbanos e a cultura local}

Se o século XIX é o de delinear a nova forma de ocupação da região portuária e com a inauguração do que é conhecido como Porto do Rio, na primeira década do século $X X$, é nas décadas seguintes que veremos diferentes planos e projetos governamentais de intervenção tendo a zona portuária do Rio de Janeiro como objeto. Diversas em seus objetivos, as propostas apresentaram em comum uma falta de uma política habitacional para a região e para o Morro da Providência, em particular.

Com nomenclaturas alternativas - renovação urbana, revitalização ou mesmo reabilitação urbana - todos os projetos e planos visam gerar novas dinâmicas, principalmente econômicas, na área do entorno do Porto do Rio. Cabe uma pequena lembrança em relação a estas denominações. Segundo Ferrara (1988), os nomes dados às intervenções urbanas representam projetos diferentes. Segundo a autora, renovações urbanas são próprias dos projetos de destruição/demolição/desmonte que buscam dar um ar de modernidade e racionalidade antes da emergência do novo, do construído. Já o termo "revitalização urbana" representaria um projeto que daria uma nova vitalidade - econômica, cultural, física e simbólica - às áreas. Entendemos que pode ser considerado, também, como um projeto que vise a "dar vida" às áreas degradadas. $\mathrm{O}$ termo "reabilitação urbana" parece-nos que traz, ainda, um conceito da medicina 
para um "paciente enfermo" ou mesmo um conceito sociológico de tratar o espaço urbano "marginal" visando torná-lo um novo e funcional espaço. Algo como uma segunda chance urbana. E essa outra chance seria obtida através da revalorização econômica, social e funcional da região.

O desenvolvimento de novas tecnologias provocou a diminuição da necessidade de mão de obra para trabalhar nas atividades portuárias. Além disso, o armazenamento dos produtos exportados/importados passou a ser realizado em contêineres. Assim, com o tempo, os grandes armazéns perdem as suas funções e diminuem o número de trabalhadores na região portuária. Com isso, toda uma gama de atividades de comércio e serviço ancoradas na carga e descarga de mercadoria que articulavam, também, a população e o perfil habitacional dos bairros da Saúde, Gamboa e Santo Cristo vai ser afetada.

Os estivadores, arrumadores de carga, conferentes e portuários junto com seus familiares se estabeleciam na Região - notadamente no Morro da Conceição, Morro da Providência,
Morro do Pinto e Morro da Saúde. Ainda hoje, ao se percorrer a região encontramos aposentados e familiares de trabalhadores do porto em suas diversas funções. E, junto com eles, as práticas, relações sociais e possíveis identidades que povoam a zona portuária.

Tratando-se de uma área com infraestrutura urbana na planície e nos Morros da Conceição e do Pinto, a região passou a ser objeto de desejo de empresários para reocuparem o lugar, mudarem seus usos e garantir lucros imobiliários. Mas, dos diversos projetos e programas pensados para a região, o único projeto que acabou saindo do papel foi o denominado "Porto Maravilha".

O projeto Porto Maravilha foi elaborado no bojo da candidatura da cidade do Rio de Janeiro à sede dos Jogos Olímpicos no espírito instituído no Plano Estratégico da cidade. É um projeto que traz como novidade a ancoragem cultural como dinamizador do território. A concepção é a construção de instituições que ancorariam a nova ocupação do território. A nau volta ao porto, agora como empreendimento cultural: o Museu de Arte do Rio (MAR), o Museu 
do Amanhã e o Aquário Marinho do Rio de Janeiro - AquaRio.

No projeto original também é pensada uma novidade: uma política habitacional que iria trazer novos moradores e garantiria uma mistura de atividades na região: moradias, instituições culturais, comércio e serviços.

Porém, do projeto inicial, apenas a ancoragem cultural se manteve. Sem uma política de incentivo à moradia, apenas os moradores anteriores ao projeto se mantiveram. E, mais, a única política habitacional foi o projeto de remoção de parte dos pouco mais de 4 mil moradores do Morro da Providência.

Neste ponto vale a pena lembrarmos que o Projeto Porto Maravilha abrange os bairros da Saúde, Gamboa e Santo Cristo deixando do lado de fora apenas o Morro da Providência. Assim, a política habitacional de remoção ficou a cargo da Secretaria Municipal de Habitação. Quando estivesse concluída, aí sim, o Morro da Providência passaria a integrar o projeto "Porto Maravilha". O ônus da remoção ficaria com o poder público e o bônus de um morro "embelezado" ficaria com a iniciativa privada.

Mas, outra constatação do projeto "Porto Maravilha" era que o conceito de revitalização urbana ancorado nos grandes empreendimentos culturais negavam ou "esqueciam" a produção cultural já existente no território.

Conforme apresentado por Guerreiro (2013), antes do projeto ser apresentado ao Comitê Olímpico (2009), os coletivos culturais, artistas e instituições culturais existentes já estavam se organizando em rede.

Em 2007, no Centro Cultural Ação da Cidadania (atual Armazém Cidadania e Cultura) foi lançado o I Fórum de Dinamização Cultural da Zona Portuária. Resultado de um levantamento sociocultural realizado por integrantes do Instituto Bandeira Branca de Desenvolvimento Social (IBB) - responsável pelo projeto Batucadas Brasileiras - foram identificadas 30 (trinta) instituições formalizadas ou não como associações de moradores, sindicatos, movimentos culturais, sociais e comunitárias da Zona Portuária. A área onde ocorreu o levantamento corresponde ao mesmo território que 
depois será objeto de intervenção do projeto Porto Maravilha.

De acordo com uma reportagem da revista Batucadas Brasileiras (2007) intitulada "Zona Portuária se une no Porto Cultural" representantes do Fórum Porto Cultural informaram, na ocasião, que "após décadas como meros joguetes de diatribes políticas e especulação imobiliária, os moradores e trabalhadores da Zona Portuária pretendem tomar o timão do futuro da região." (p. 42).

A construção do Fórum se deu durante todo ano de 2007 com a participação mais efetiva das seguintes instituições que assinam a carta manifesto de fundação do Porto Cultural: Centro Cultural Ação da Cidadania - CCAC, IBB - Instituto Bandeira Branca de Desenvolvimento Social, Associação Cultural Recreativa Afoxé Filhos de Gandhi, Instituto de Pesquisa e Memória Pretos Novos, Centro Cultural dos Rodoviários, Grande Companhia Brasileira da Mystérios e Novidades, Sparta Associação Esportiva do Morro da Providência, Tonpi-Nheco 07, Ribeiro Promoções e Eventos, Instituto Sociocultural Favelarte, Spectaculu e Instituto Nacional de Tecnologia.
Assim, o objetivo do Porto Cultural seria o de provocar a sinergia entre as diversas ações já existentes na região, ajuda mútua para a consolidação de outras e procurar uma agenda comum que agregasse todas as entidades num Plano de Ação onde pudessem executar atividades e pressionar o poder público para as melhorias que a região necessita.

A proposta era tomar a frente das políticas públicas socioculturais de forma com que os grupos participantes garantissem sua autonomia e sustentabilidade.

Resumindo, a articulação política dos atores socioculturais da Região Portuária autodenominada Porto Cultural tinha como ambição agregar as ações culturais e sociais da Zona Portuária e interferir nos projetos pré-existentes e que, até então, não tinham saído do papel. A busca era para que a dinamização que estava prestes a acontecer levasse em conta, principalmente, a população local, inserindo-a e não a expulsando.

O Nômade chegou ao Morro da Providência a partir do convite de outro projeto, o Viaduto Literário, criado pela moradora Marcia Raquel, mãe de dois ex-alunos das nossas aulas de teatro. 
O Viaduto também propõe uma ocupação coletiva da Praça da Marquês com as crianças, produzindo rodas de leituras, contações de histórias, oficinas e compartilhamento de afetos. Embora nem o Nômade nem o Viaduto existissem no momento do Porto Cultural, há nessas ações questões que se assemelham. Segundo Deleuze (1997), não é necessariamente deslocamento que caracteriza o nomadismo, mas sim a relação com o território que ocupa. O nômade, no sentido dicionarizado, é aquele errante, o que não tem pouso fixo, o que vaga. Em Deleuze, o que faz nomadismo é o percurso permanente, pois o nômade não toma território, se apropria daquele espaço por meio do uso que se faz dele. O nômade não é aquele que quer a propriedade do espaço, ele quer atravessar o espaço, usar o espaço, e assim, modificá-lo.

Para Certeau, há uma distinção entre lugar e espaço. Enquanto o primeiro aponta para uma estabilidade, o segundo indica variável, movimento. Um não é a exclusão do outro, ambos se transformam num e noutro por meio dos relatos, dos efeitos que se produzem nas operações de usos.
"Em suma, o espaço é um lugar praticado. Assim a rua geometricamente definida por um urbanismo é transformada em espaço pelos pedestres." (CERTEAU, 2014, p. 184) Lugar é aquilo que define, que ordena, enquanto espaço está em variação a partir das ações dos sujeitos históricos. Não se trata aqui de ser espaço ou lugar, liso ou estriado. Ao trabalhar o estriado como liso, o nômade faz uma operação de afeto, de transformação pelo hábito, pelo uso. E aqui, mais uma vez, nos aproximamos de Certeau (2014), que vê, nos movimentos de caminhada, uma falta, uma errância que priva de lugar, e, portanto, de identidade. Dessa forma, é o habitar, o hábito, que desvela um espaço.

Era esse habitar, que fala de uma relação direta desses moradores com o espaço, podendo ele ser ao mesmo tempo praça, porto, palco e muito mais, que estava sendo ignorado. Mais uma vez, os moradores locais não foram ouvidos pelo poder público e o projeto Porto Maravilha, além de não implementar a política habitacional para a região, desconsiderou os fazedores culturais do território. E, esses, se viram no 
meio de um processo de criação de grandes empreendimentos de entretenimento e atração de novos artistas e grupos para a região.

Como consequência, o Porto Cultural se enfraqueceu e se desarticulou. Como no projeto "Porto Maravilha" havia recurso para financiar atividades culturais pré-existentes no território, a relação com o órgão gestor do projeto se deu individualmente. Divididos, ficaram mais fracos nas negociações.

Assim, quando o Projeto Teatro Nômade desembarca em um território da região portuária que não se caracteriza nem como Morro da Providência, nem Morro do Pinto e, muito menos é considerado parte do bairro do Santo Cristo, muitas lutas, resistências e produções artísticoculturais já tinham marcado essa região. Organizados na época do Porto Cultural ou fazendo parcerias e ações solidárias como agora, os grupos culturais da região do "festejado" projeto imobiliário Porto Maravilha continuam seu caminho apesar e a despeito do poder público que muitas vezes os invisibilizam. Mas, tragamos luz à fronteira!

\section{Todo menino é um rei}

Em seu livro $O$ teatro do oprimido e outras poéticas políticas, Augusto Boal afirma que "todo teatro é necessariamente político, porque políticas são todas as atividades do homem, e o teatro é uma delas." (BOAL, 2010, p. 11). Para Luiz Antônio Simas (2019), as ruas da cidade estão em permanente disputa política entre as classes dominantes $e$ os subalternizados. Entendemos que o trabalho desenvolvido pelo Nômade é político na encruzilhada dessas duas dimensões.

No princípio, o teatro era o canto ditirâmbico: o povo livre cantando ao ar livre. O carnaval. A festa.

Depois, as classes dominantes se apropriaram do teatro e construíram muros divisórios. Primeiro, dividiram o povo, separando atores de espectadores: gente que faz e gente que observa. Terminou-se a festa! Segundo, entre os atores, separou os protagonistas das massas: começou o doutrinamento coercitivo! O povo oprimido se liberta. E outra vez conquista o teatro. É necessário derrubar muros!

(BOAL, 2010, p. 177)

O carnaval é perigoso. O controle dos corpos sempre foi parte do projeto de desqualificação das camadas historicamente subalternizadas como produtoras de cultura. Esse projeto de desqualificação da cultura é base da repressão aos elementos lúdicos e sagrados do cotidiano dos pobres, dos descendentes dos escravizados, e de todos que resistem ao confinamento dos corpos e criam potência de vida. $O$ corpo carnavalizado (...) dono de si, é 
aquele que escapa (...) ao confinamento da existência como projeto de desencanto e mera espera da morte certa. O carnaval é o duelo entre o corpo e a morte. (SIMAS, 2019, p. 110)

O corpo teatral carnavalizado é um corpo livre e consciente (mas o que significa um corpo livre e consciente? Livre do que? Consciente de quê?), perturbador da ordem que se pretende impor às ruas. Ao expor nosso trabalho, nossa presença nas ruas, reafirmamos um lugar político. Um dos objetivos do ensino do teatro na formação básica do sujeito é justamente ir na contramão de relações pré-estabelecidas, mostrando outras possibilidades de uso dos corpos.

A escola ocidental, fundamentada no ensino seriado e na fragmentação de conteúdo, é geralmente normativa, padroniza comportamentos e corpos. $\mathrm{E}$ a diferença? A rua poderia resolver isso. Se a escola normatiza, a rua deveria ser o lugar capaz de permitir o convívio entre os diferentes. (...)

Pedagogia infantil, insisto, é deixar a criança brincar e desenvolver aptidões ludicamente. O resto é formar gente triste para os currais do mercado de trabalho. A criança precisa da arrelia das brincadeiras, e a humanização do mundo passa como um espaço de folguedo, flozô e furdunço - pelo encantamento radical da rua. (SIMAS, 2019, p. 134-136)

Estendemos as considerações de Luiz Antonio Simas para além das crianças, pois acreditamos que a educação em todas as idades necessite de encantamento. Aula de teatro é também espaço para o lúdico, em todas as idades, tomar conta. É lugar de liberdade do corpo, do convívio com o outro, com o espaço. Ser professora de teatro não significa ensinar ninguém a ser ator. Significa poder mostrar possibilidades outras de estar no mundo. Não é "poder ser outra pessoa", como já ouvimos diversas vezes, é poder ser a gente mesmo. Em uma educação para a disciplinarização, é preciso ficar sentado em uma mesma posição, sem se mexer demais, sem deitar, sentar, levantar, falar. Apenas na hora certa, quando for solicitado. $O$ ensino do teatro, por permitir a exploração do que pode um corpo, transgride regras e incomoda ambientes coercitivos apenas pela sua existência.

Apesar das múltiplas experiências dando aula na rua em anos anteriores, o começo do trabalho com essa turma foi muito difícil, e quase sempre voltávamos das aulas em desespero. Muitas vezes, absolutamente nada do nosso planejamento era aproveitado, com o sentimento de "tudo deu errado" nos dominando. Além dos já narrados 
encontros com a PM, lidávamos com a violência dos alunos entre eles e com as dificuldades de constituir uma turma. Passamos então a buscar parte dos alunos em casa, desviando o nosso caminho de chegada para passar pela rua onde moram. Durante muito tempo debatemos e nos questionamos se isso contribuía para o trabalho ou não, e até hoje não temos uma resposta única e clara. Mas, ao buscá-los em casa criamos uma turma, ainda que muito, muito fluida, pois vários começavam a aula e iam embora no meio, ou chegavam atrasados. Havia também, claro, as faltas por motivos diversos $\mathrm{e}$ as aparições de um dia só, em geral de crianças que já estavam brincando na praça quando chegávamos e quando viam a movimentação vinham fazer a aula. Com o tempo entendemos que o nosso processo de aprenderensinar, e até mesmo aquilo que fixamos como conceito de aula, pode ser repensado a partir do nosso encontro com essa turma. Os caminhos de ida e volta não eram silenciosos e isentos de tensões, eram também momentos em que construíamos conhecimentossignificações com eles.
Depois de alguns meses de trabalho decidimos fazer uma aula aberta que apresentaríamos com eles, e próximo à data que estipulamos chegamos a uma frase que dizia muito sobre nossas práticas. "Precisamos estar preparadas para acontecer tudo, inclusive para nada". Mas o que é "nada"? Nada do que planejamos, nenhuma das expectativas que desejávamos depositar nos alunos.

Logo antes de seu duelo com Laertes, Hamlet diz a Horácio que está com um mau pressentimento. Esse duelo virá a ser o de sua morte, mas ele ainda não o sabe. Horácio pede que o amigo respeite sua intuição, mas Hamlet responde que o que tiver de acontecer, acontecerá de qualquer forma, e sentencia: "estar preparado é tudo" (SHAKESPEARE, 1988, p. 613). Assim como Hamlet, é preciso estar preparado quando entramos em sala de aula, para tudo que acontecerá, principalmente para a morte das nossas expectativas.

Em Jogos teatrais, Ingrid Koudela, professora e pesquisadora da pedagogia do teatro, afirma que:

O teatro, enquanto proposta de educação, trabalha com o potencial que todas as pessoas possuem, transformando esse recurso natural em um processo consciente de 
expressão e comunicação. A representação ativa e integra processos individuais, possibilitando a ampliação do conhecimento da realidade. (KOUDELA, 2009, p. 78)

A ideia de que o teatro é um recurso natural de todos os seres humanos e que ao professor cabe o papel de potencializador do aluno aparece também em Boal:

O Teatro do Oprimido, em todas as suas formas, busca sempre a transformação da sociedade no sentido da libertação dos oprimidos. É ação em si mesmo, e é preparação para ações futuras. "Não basta interpretar a realidade: é necessário transformá-la!" - disse Marx, com admirável simplicidade. (BOAL, 2010, p. 19)

As reflexões de Boal, que apontam o teatro como forma de emancipação do ser humano, encontram as de Paulo Freire, que traz a emancipação do sujeito pela educação:

Por isso mesmo pensar certo coloca ao professor ou, mais amplamente, à escola, o dever de não só respeitar os saberes com que os educandos, sobretudo os das classes populares, chegam a ela - saberes socialmente construídos na prática comunitária mas também, como há mais de trinta anos venho sugerindo, discutir com os alunos a razão de ser de alguns desses saberes em relação com o ensino dos conteúdos.(...)Por que não discutir com os alunos a realidade concreta a que se deva associar a disciplina cujo conteúdo se ensina, a realidade agressiva em que a violência é a constante e a convivência das pessoas é muito maior com a morte do que com a vida? (FREIRE, 1998, p.33)
Dessa forma, os alunos e sua produção artística, intelectual e cultural aparecem como sujeitos ativos. Como aponta Marina Henriques Coutinho em seu livro $A$ favela como palco e personagem, no qual faz uma análise das políticas sociais e culturais implementadas em comunidades ao longo das últimas décadas, “(...) a noção de participação foi adotada pelas políticas desenvolvimentistas, mas, em muitos casos, serviu mais como um discurso conivente; bem longe da práxis eficiente, na qual acreditava Paulo Freire." (COUTINHO, 2012, p. 135). Tomando os beneficiados pelos programas sociais como manequins em vitrines, tal qual as alterações urbanas que abordamos no início desse artigo, essas políticas contribuem mais para manter a ordem vigente do que para questioná-la:

A efetiva presença da política defendida pelos dois brasileiros [Boal e Freire] depende das intenções do "projeto". E elas podem variar: algumas comprometidas com a verdadeira interação entre as pessoas, o questionamento da realidade e a necessidade de mudança; outras, fruto de agendas mais ocultas, servindo como instrumento para objetivos ilusórios e sem qualquer impacto na vida das pessoas. (COUTINHO, 2012, p.136) 
Assim, pretendíamos construir uma relação com a turma na rua que não se baseasse em pressupostos e preconceitos, mas que estivesse aberta à possibilidade de mudança e transformação, entendendo que o lugar do professor não pode passar por uma hierarquia pré-fundamentada em relação aos alunos. Se para Boal o papel do teatro é transformador, é preciso fazer disso uma constante: não apenas um objetivo salvador do outro, mas de nós mesmos.

Mas não foi em Boal que encontramos um caminho para os problemas que enfrentávamos. Quem nos valeu foi Beatriz Ângela Cabral e o Drama como método de ensino (2006). Chegando próximo à nossa aula aberta as duas professoras tinham a sensação de que nada tinha acontecido em todos aqueles meses, quase um ano de trabalho, e que de professoras de teatro tínhamos passado a babás das crianças, que queriam correr no parquinho em todas as aulas e não tinham nenhum interesse no que estávamos propondo. Em um dia especialmente confuso, em que elas não nos ouviam, corriam para todo lado e se batiam a cada minuto, gritamos um "chega, acabou a aula, vamos embora". A resposta deles foi: "mas já, tia? A gente nem fez aula". Bom, não tinham feito mesmo. Mas ali descobrimos que eles percebiam isso, que sabiam diferenciar o que era a nossa aula com eles e o que era a brincadeira entre eles.

Foi a partir dos usos do espaço que fomos construindo nossas trocas na Praça da Marquês com as crianças. $E$ um dia encontramos um aluno que tinha parado de frequentar as aulas de teatro. Perguntamos por onde ele andava, já que ele era um dos mais interessados, sempre. Ele disse que nos dias da aula de teatro ele tinha passado $a$ ir em um outro projeto social que atua na Providência, estava fazendo aulas de futebol. "Mas que horas é a aula lá?"“'18h."'Ah, então. Nossa aula é às $17 \mathrm{~h}$, é tão pertinho, você pode ficar aqui com a gente um pouco e depois ir para lá." "Não dá, tia. Lá não pode atrasar. Se atrasar tem que correr 10 vezes em volta da quadra. E se atrasar várias vezes não pode mais entrar. Lá é só para quem quer."

"Lá é só para quem quer" soou estranho. O que isso significa? Anos antes, em outras ocasiões, nós já havíamos feito algo semelhante, 
limitando o número de faltas dos alunos. Quando há uma porta para fechar existe um poder, mas quando se está na rua esse poder é retirado.Afinal, não somos donas da rua. Ali, a aula é para quem veio ver a aula e para quem estiver passando. Todos que estiverem ali ouvindo estão tendo aula também. Se houver atraso fará aula, se não vier um mês e depois aparecer de novo fará aula. Mas como nós professoras lidamos em uma mesma turma com quem vem a todos os encontros e com quem some dois meses, aparece um dia, some mais dois meses? O que se constrói? É possível ter um trabalho continuado? O poder não está mais na porta, e agora? Em Andrade e Caldas (2017), no artigo Barulho de escola entre grades e muros: o que é ser livre na escola?, elas mostram que os muros da escola são lidos como proteção por uns e cerceamento da liberdade por outros, e mostram as táticas dos estudantes para subverter a lógica dos muros e das grades. Andrade narra o momento em que percebeu "que não bastava abrir cadeados ou desfazer as grades. Era preciso produzir novas relações, mais emancipatórias, menos opressoras, com mais protagonismo e menos proteção para que pudéssemos romper de fato com as grades." Chorando no transporte público depois de um dia de aula especialmente exaustivo, também começávamos a perceber que algo na nossa relação com aqueles alunos precisava mudar.

\begin{abstract}
Para que alguma coisa relevante ocorra, é preciso criar um espaço vazio. O espaço vazio permite que surja um fenômeno novo, porque tudo que diz respeito ao conteúdo, significado, expressão, linguagem e música só pode existir se a experiência for nova e original. Mas nenhuma experiência nova e original é possível se não houver um espaço puro, virgem, pronto para recebê-la.

Posso escolher qualquer espaço vazio e considerá-lo um palco nu. Um homem atravessa este espaço vazio enquanto outro o observa, e isso é suficiente para criar uma ação cênica. (BROOK, 2011, p. 4)
\end{abstract}

Embora voltado para atores e diretores, A porta aberta, de Peter Brook, diretor de teatro, mostrou algumas reflexões possíveis. O espaço vazio de Brook traz a lembrança de que, para o teatro acontecer, o que menos importa é o edifício teatral. $O$ nosso teatro acontecia a cada vez que criávamos na praça um espaço vazio. Aliando essa perspectiva ao que trazíamos do Drama como método, nossas aulas ficaram mais leves, nossa relação com os alunos se aprofundou e eles começaram a nos 
esperar na porta de casa para a aula de terça-feira.

O Drama como método de ensino foi criado na Inglaterra e chegou ao Brasil por meio do livro homônimo de Beatriz Ângela Cabral. Essa metodologia surge como um contraponto ao "teatro tradicional" feito nas escolas, em geral muito baseada no sistema de Stanislavski, e avalia professores e alunos por uma apresentação final previamente ensaiada. No drama como método (entendendo por drama o próprio fazer teatral, a criação de uma dramaturgia), o foco está na criação do cotidiano da sala de aula, em que os próprios alunos desenvolvem uma história. Assim, jogos teatrais e conteúdos do ensino do teatro são inseridos dentro de uma narrativa criada pelos alunos, coletivamente. Ali na praça com os nossos pequenos Nômades, o Drama ia muito além dos alunos, envolvendo e fazendo rizoma (DELEUZE, 1997) com os brinquedos da praça, com quem estivesse passando, com a quadra de futebol. Não havia quarta parede a ser quebrada, porque não havia mais muros, não havia dentro e fora.
Quando começamos a trabalhar para a nossa aula aberta, ou seja, costurar os fragmentos de história que vínhamos criando, dois irmãos nos chamaram a atenção. Ambos estavam sempre pela praça, muitas vezes vinham lanchar com a gente no início das aulas, mas poucas vezes participavam do que estávamos propondo como jogo. Um deles, no início no nosso processo com a turma, tinha passado a aula rondando o grupo, caçoando do trabalho que fazíamos e batendo nos mais novos. Ao final, quando propusemos uma atividade de desenho coletivo em uma cartolina, ele pediu um lápis. Desenhou um pênis enorme no meio da folha e foi embora, deixando as crianças chorando porque o desenho delas estava arruinado. Um dia, estávamos construindo uma parte da nossa dramaturgia em que nós, como marinheiros, desembarcávamos em uma ilha, a praça. Um dos irmãos estava no alto de um escorrega, observando de longe. Apontamos para ele: "marinheiros, ali está o castelo do rei que estamos procurando! Vamos lá falar com o rei." Fomos até ele e desenvolvemos uma cena de improvisação dos marinheiros com o 
rei. Nesse dia, ele veio perguntar se poderia ter uma coroa. E nunca mais deixou de fazer uma aula, assim como seu irmão, que no dia em que trouxemos a coroa (explicamos que seria uma coroa para todos e todos poderiam usar em algum momento, ao que ele respondeu: "tudo bem, tia, todo mundo pode usar a coroa, eu sei que o rei sou eu"), colocou na cabeça, no alto do escorrega, e abriu o primeiro sorriso que o havíamos visto dar durante todo o ano. Quando explicamos que depois da aula aberta entraríamos de férias, os dois irmãos se revoltaram, dizendo que não tinha motivo para entrar de férias e que além disso a "apresentação" estava muito curta.

A narrativa do rei no alto do escorrega fala das táticas que nós usávamos no momento oportuno (CERTEAU, 1994) para ampliar as redes educativas que ali se davam. Era no fazer e refazer constante do nosso planejamento que íamos formando os currículos do nosso ensino ali, no qual como professoras tínhamos mais liberdade do que nunca. Nossa liberdade era tanta, que não tínhamos nem mesmo um tempo de aula definido, ela durava o tempo que conseguíssemos sustentar uma relação de prazer e aprendizagemensino.

No dia da aula aberta, apesar de termos preparado tudo, comprado material, criado figurinos e adereços, chegamos na praça sem saber o que ia acontecer. Os nossos alunos iriam? Outras crianças estariam lá? Elas iriam querer se apresentar ou estariam naqueles dias em que só queriam correr, gritar e bater uns nos outros? A aula aberta foi muito melhor do que jamais poderíamos imaginar. Havia uma tranquilidade nunca antes vista.Saímos de lá achando que, agora sim, tínhamos uma turma unida, presente, com desejo no teatro. $\mathrm{Na}$ aula seguinte, nossa última antes das férias, a praça parecia um filme de apocalipse. Nós gritávamos, eles corriam, o planejamento estava no chão. O jogo nunca está ganho. Começamos a arrumar as coisas arrasadas, quando algumas meninas mais velhas, que tinham passado a aula aberta caçoando dos menores, vieram falar com a gente que no ano seguinte seriam nossas alunas, queriam fazer teatro. $\mathrm{O}$ jogo também nunca está perdido. 
Quando, depois das férias de fim de ano, o Nômade retornou às aulas em janeiro, fomos surpreendidos pela ansiedade deles em voltar para as aulas de teatro. Quando foi pedido que eles subissem em um dos brinquedos da praça para começarmos a aula, um aluno de quatro anos disse "vamos subir no barco!". Na nossa aula aberta, meses antes, quando criamos a história dos marinheiros que encontravam o rei, os jogos que criamos nos levaram a estabelecer um dos brinquedos como o barco dos marinheiros. Esse reconhecimento lembra o de uma outra aluna, que no dia da aula aberta olhou o mural que montamos com a exposição de trabalhos feitos por eles ao longo do ano e disse: "tia, aqui tem desenhos meus". Ela apontou, no mar de desenhos, colagens e pinturas, os que ela havia feito e ainda disse em que aula, como: "Esse aqui é o Minotauro." "Esse foi na aula do mar."

Esses dois momentos mostram que há uma memória sendo produzida nos nossos encontros. A praça é, naquele momento, palco, ilha encantada, sala de aula, mar aberto, galeria de arte. A relação estabelecida com o espaço urbano, habitado pelos moradores a partir de diversos usos criados nos cotidianos, transforma território em terreiro (SIMAS, 2019), espaço encantado de conhecimentossignificações. A zona portuária vem sendo parte de uma cidade em constante disputa, desde suas primeiras ocupações, passando pelo Porto Cultural e chegando aos dias de hoje com ações como o Viaduto Literário e Projeto Teatro Nômade.

Historicamente, as estratégias usadas pelo poder público para uma apropriação do porto e das praças do Rio de Janeiro têm contribuído para um violento apartamento entre moradores e seu território, apagando direitos e pertencimentos. Por isso, se faz importante pensar as ruas da cidade como possíveis espaços educativos a partir dos usos que os próprios moradores fazem.

\section{Referências bibliográficas}

ABREU, Maurício de Almeida. Evolução Urbana do Rio de Janeiro. Rio de Janeiro: IPP, 1988.

ABREU, Maurício de; VAZ, Lilian Fessler. Sobre a origem das favelas. Anais do IV Encontro Nacional da ANPUR, Salvador, 1991, p. 481-492.

ANDRADE, Nívea; CALDAS, Alessandra Nunes. Barulho de escola 
entre grades e muros: o que é ser livre na escola?Revista Educação e Realidade, v.42, $\mathrm{n}^{\circ} 2,2017$. Disponível em:

http://www.scielo.br/scielo.php?script= sci_arttext\&pid=S2175-

$62362017000200495 \&$ lng $=p t \& n r m=i s o$ \&tlng=pt. Acesso em: 02 jan. 2020

ANJOS, Ana Maria de la Merced Gonzalez Grana Guimarães dos. Entrevista concedida a João Guerreiro. Rio de Janeiro, 07 de janeiro de 2013.

ATHAYDE, Antonio Carlos.Catálogo da Exposição Africanos novos na Gamboa: um portal arqueológico.Rio de Janeiro, Arquivo Geral da Cidade do Rio de Janeiro, 2001, 32 p. Disponível em: http://www0.rio.rj.gov.br/arquivo/pdf/cat alogo_exp_pdf/africanos_gamboa.pdf. Acesso em: 25 mar. 2013.

BENCHIMOL, Jaime. Pereira Passos, um Haussmann tropical: as transformações urbanas na cidade do Rio de Janeiro no início do século $X X$. 2 v. Dissertação (Mestrado em Planejamento Urbano e Regional). Universidade Federal do Rio de Janeiro, 1982.

BOAL, Augusto. Jogos para atores e não-atores. Rio de Janeiro: Civilização Brasileira, 2011.

BOAL, Augusto. Teatro do oprimido e outras poéticas políticas. Rio de Janeiro: Civilização Brasileira, 2010.

BROOK, Peter. A porta aberta. Rio de Janeiro: Civilização Brasileira, 2011.

CABRAL, Beatriz Ângela Vieira. Drama como método de ensino. São Paulo: Hucitec, 2006.

CERTEAU, Michel de. A invenção do cotidiano: 1. Artes de fazer. Rio de Janeiro: Vozes, 2014.
COUTINHO, Marina Henriques. $A$ favela como palco e personagem. Petrópolis: DP et Alii/FAPERJ, 2012.

DE PAULA, Richard N. Semente de favela: jornalistas e o espaço urbano da capital federal nos primeiros anos da República: o caso do Cabeça de Porco. Revista Eletrônica de História do Brasil, 6(1), p. 36-53, 2004.

DELEUZE, Gilles; GUATARI, Félix. Mil platôs. São Paulo: Editora 34, 1997.

FERRARA, Lucrecia D'Alessio. A Cidade. São Paulo: Nobel, 1988.

FREIRE, Paulo. Pedagogia da autonomia. São Paulo: Paz e Terra, 1998.

GILROY, Paul. O Atlântico Negro: modernidade e dupla consciência. Rio de Janeiro: Ed. 34, 2002.

GUERREIRO, João. Quando o centro é a periferia: dinâmica cultural na região portuária do Rio de Janeiro. Tese (Doutorado em Serviço Social). Universidade Federal do Rio de Janeiro, 2013.

KOUDELA, Ingrid Dormien. Jogos teatrais. São Paulo: Perspectiva, 2009.

LAMARÃO, Sérgio.Dos trapiches ao porto: uma contribuição ao estudo da produção da área portuária do Rio de Janeiro. Dissertação (Mestrado em Planejamento Urbano e Regional). Universidade Federal do Rio de Janeiro, 1984.

MELLO, Fernando Fernandes de. $A$ zona portuária do Rio de Janeiro: antecedentes e perspectivas. Dissertação. (Mestrado em Planejamento Urbano e Regional). Universidade Federal do Rio de Janeiro, 2003.

SHAKESPARE, William. Obra completa. Volume 1. Rio de Janeiro: Nova Aguilar, 1988. 
SIMAS, Luiz Antônio. O corpo encantado das ruas. Rio de Janeiro: Civilização Brasileira, 2019.

ZYLBERBERG, Sonia (coord.). Morro da Providência: memórias da "favella". Rio de Janeiro, Secretaria Municipal de Cultura, Turismo e Esportes, Departamento Geral de Documentação e Informação Cultural (Coleção Memória das Favelas, vol.1). 1992. 